\title{
ENHANCING ACTIVIST SCHOLARSHIP IN NEW ZEALAND AND BEYOND
}

\author{
HEATHER CAME \\ SCHOOL OF PUblic Health and PSYCHOSOCLAL STUdIES, AUCKL AND UNIVERSTTY OF TECHNOLOGY \\ JOEY MACDONALD \\ MARIA HUMPHRIES \\ WAIKATO MANAGEMENT SCHOOL, UNIVERSITY OF W AIKATO
}

\begin{abstract}
Aotearoa (also known as New Zealand) is a jurisdiction that must respond to the inequitable elements of the multi-facetted oppressions of its colonising past and present if it is to live up to its claim to being an honourable nation. Early intensification of colonising practices embedded European values over those of the indigenous people with lasting devastating effects. In search of a national integrity, activist traditions of exposure, resistance, dissent and non-violent direct action to injustices are longstanding in this land. Activist scholarship however, is a more recent phenomenon. We explore the potential of activist scholarship to contribute more directly to transformations that will embed justice in the diverse socio-political economic context of New Zealand. We outline what we understand by activist scholarship and how we believe it can strengthen both socio-political activism and academic scholarship in synergistic ways. We propose seven principles of activist scholarship, generated through on-going dialogue with our activist scholar peers. We offer them as a starting point for discussion and critique until a collective statement emerges. We showcase Ngāpuhi Speaks as an example of such potential synergies.
\end{abstract}

\section{Keywords}

Social protest, activist scholarship, New Zealand, Treaty of Waitangi, social change

Corresponding author:

HeatherCame,Email: bcame@aut.ac.nz.

The authors send thanks to Tony Dowsett and Steve Edwards (aka Snoopman) for comments on this paper and to Sue Bradford and our Kotare activists friends for the many conversations which informed this paper. 
All that separates, whether of race, class, creed, or sex, is inhuman, and must be overcome ${ }^{1}$

$\mathrm{N}$ ew Zealand is a jurisdiction that must respond to the inequitable elements of race, class and gendered oppressions of its colonising past and present if it is to live up to its claim to being an honourable nation. As left-orientated Pākehā ${ }^{2}$ activist scholars committed to the enhancement of moral integrity in and with this land, we are interested in diverse and interlocking systems of oppressions, described by Crenshaw (1989) as intersectionality. We examine the potential of activist scholarship to contribute to transformations that will embed justice in the diverse socio-political context of New Zealand and beyond. We outline what we understand by activist scholarship and our belief that the intensification of this form of research can strengthen both socio-political activism and academic scholarship in synergistic ways. We propose seven principles of activist scholarship to further this genre of activism in Aotearoa (the Māori name for New Zealand) and for their enhancement by a broader community of activistinclined scholars. Presented below in Table 1, these principles have been generated through ongoing dialogue with our activist scholar peers. We offer them as a starting point for discussion and critique until a collective statement emerges. We showcase Ngāpuhi Speaks as an example of such potential synergies.

This paper is an outcome from an intended collaboration between activists and researchers, who met through forums organised at the Kotare Centre for Social Change and elsewhere. ${ }^{3}$ The project to publish together however, became more complicated than we had envisaged. It was decided to regroup and prepare an exploratory paper to serve as a base for future collaborations of activist scholars, on the intersection of oppressions within the specifics of a neo-colonial context. We acknowledge the significant Māori ${ }^{4}$ contribution to activist scholarship in this land and thus on our work. Māori views will not be substantially addressed within this paper. Instead we direct readers to Ngā Pae Māramatanga ${ }^{5}$, a national centre for research excellence, as an introduction to this significant body of work. Our intention is to write and be accountable as Pākehā in this land and as non-indigenous activist scholars in the global context. We begin by situating ourselves and our research in the socio-political context of Aotearoa by those with a de-colonising attitude to this land.

\section{Socio-political context of New Zealand}

It is not the mountain we conquer, but ourselves ${ }^{6}$

Traditionally Māori are organised through independent hapū (nations) often with familial and diplomatic connections via whakapapa (genealogy). Māori were recognised as a confederation of independent nations within the international community in 1835 through He Wakaputanga o

\footnotetext{
1 Sheppard quoted in Paxton and Hughes (2007, p. 47).

2 Pākehā is the collective term for settlers who came from a variety of cultural backgrounds after Māori settlement of New Zealand.

3 Kotare is a centre for research and social change education based in Hoteo North (http://kotare.org.nz/).

4 Māori is the collective name of the indigenous people of New Zealand.

5 Learn more from their website http://www.maramatanga.co.nz/.

6 Hilary quoted in Kuchler (2003).
} 
te Rangatiratanga Nū Tūrei (Declaration of Independence) (Healy, Huygens, \& Murphy, 2012). Governance arrangements and settlement were later negotiated with the British through Te Tiriti o Waitangi ${ }^{7}$, which affirmed Māori tino rangatiratanga (sovereignty) and guaranteed ōritetanga (equity) with British citizens.

Through the use of military force, legislation, and sheer cultural, political and economic dominance, the British imposed Eurocentric systems of governance, land tenure, law and social development. Māori resistance to this imposition and advocacy for Māori sovereignty has been ongoing since then (Walker, 1990). The promises made to Māori as articulated in Te Tiriti and in much contemporary policy speak, have yet to be substantially honoured. Historic and contemporary treaty breaches, for example, continue to be investigated through the Waitangi Tribunal ${ }^{8}$. Church and State, primary historic perpetrators of institutional racism and related multifaceted oppressions are engaged in various forms of limited restitution (Orange, 2011). Public education on these matters is ongoing, but inadequate to address the systemic political apathy that underpins structural oppression. These matters of unaddressed injustice reverberate through many subsequent discussions of justice in a variety of settings. This discussion finds traction among those citizens for whom justice is a desirable national and personal characteristic.

Calls to justice and fairness, and a commitment to taking care of everyone has been an egalitarian value widely expressed by those concerned with the unequal and unjust outcomes of post Tiriti New Zealand. Such calls to justice have underpinned a variety of progressive policy initiatives (Gasson, 1998; Hackett Fischer, 2012). This value appears to be demonstrated in New Zealand's early endorsement of the United Nations (1948) Universal Declaration of Human Rights as a mechanism for achieving justice and fairness for all. Such laudable commitments, however, cannot be read as unproblematic. There have been dark sides to this self-perception. For example, New Zealand is often celebrated for being the first country in the world to give women the right to vote.

Critics of NZ's claim to global leadership in the emancipation of women based on the granting them a right to vote draw attention to the self-serving opportunistic ploy by Pākehā elite, to harness the enfranchisement of women in its early nation building interests with claims of egalitarian settler social, economic and political ideals and power over non-landowners. The landowning class-based politics of the British early settlers also disenfranchised Māori (Rei, 1993). New Zealand has since had female prime ministers, chief justices, Governor Generals and a speaker of the House of Representatives (Grimshaw, 1994). These women have presided in an era of governance that saw the intensification of apparently neo-liberal values which, through their rabid market deployment has exacerbated the marginalisation and poverty of many women. This marginalisation has compounded race, class and gendered oppressions, which are made even more complex for the elderly and the disabled as they navigate to access the rights New Zealand is proud to proclaim as universal and indivisible. While several Māori have held prestigious positions - two as Governors General - Māori remain disproportionately and often dramatically represented in all unfavourable social, political and economic statistics.

Putting aside for a moment the often unnoticed racism generated from the earliest settler elite political control over New Zealand, a raft of policies seeking an equitable society can be

7 By Te Tiriti o Waitangi we are referring to the Mãori text of the Treaty of Waitangi as signed by Hobson and the majority of Māori rangatira (chiefs) on behalf of hapū (nations) on 6th February 1840 at Waitangi (and in many other locations around Aotearoa over the succeeding seven months), not the later-signed English version (Healy, Huygens, \& Murphy, 2012).

8 The Waitangi Tribunal established in 1975 is a permanent Commission of Inquiry charged with investigating and making recommendations on claims brought by Māori related to breaches of the Treaty of Waitangi or Te Tiriti O Waitangi by Crown Ministers and/or their officials. 
named. New Zealand for example, introduced state pensions and the eight-hour working day in the late nineteenth century. This was followed by a no-fault workers compensation scheme. Tax-payer funded 'free' state-run education and health systems were established by the 1930s (Sheridan et al., 2011). The shadow side of these claims of equality and fairness, however, is entrenched invisible privilege structured along lines of gender, class, ethnicity, culture, disability and sexual orientation (Moewaka Barnes, Borell, \& McCreanor, 2014).

The intersections of historical institutional racism continue to reverberate in the present day. Māori who had compulsory education imposed on them, were channelled into domestic and manual labour and now form a significant portion of impoverished workers and unemployed. The then Christian values of Western sexuality and family structures, endorsed by this compulsory education, were laid over a more collective culture. These perhaps well-intended but harmful effects can be illustrated in the state provision of a family allowance paid only to the biological mother. This seemingly small and well intentioned policy undermined the Māori sense of collective responsibility for children infused, for example, through the kinship term whaea, which does not distinguish between mother and aunt.

Also well documented in New Zealand, are significant disparities in health (Ministry of Health and University of Otago, 2006), education (Bishop, Berryman, Cavanagh, \& Teddy, 2009), and income and wealth (Marriott \& Sim, 2014). Of all New Zealand children, $17 \%$ live in poverty (Johnson, 2015), and there is a systemic pay-equity gap between men and women (World Economic Forum, 2014). Class distinctions and oppressions are entangled with race, gender and other embedded institutionalised prejudices. Today these prejudices are exacerbated by the permissive employment laws of the neo-liberal free market regime's exploitative 'zero hour contracts' that affect disproportionately those parts of society long-oppressed (Wilson, 2014). Structural discrimination also remains embedded within the administration of the public sector (Human Rights Commission, 2011). While women, Māori and other sections of society can be found in some - but not always equal - positions of authority, the impact of this liberally inspired diversification of the elite work-force has not resulted in a more equal or just society. The prejudices of old remain largely intact and are manifest in an oppressive regime for many in this so-called land of plenty. These divisions are organised along the embedded divisions of race, class, gender, age and so forth. The causes of these divisions and their social outcomes, however, are not uncontested and, thus, the focus for their transformation is not agreed.

The source of embedded disparities and inequities in New Zealand remains contested. Some researchers make explicit an argument that ethnic disparities are the result of the ongoing impact of colonisation. Robson (2007) traces New Zealand's systemic inequities back to the social impact of the radical 'free market' structural adjustment policies of the 1980s and 1990s, which Kelsey (1995) described as the 'New Zealand experiment'. During this period, major reforms were undertaken simultaneously including a major downsizing of the public sector, promotion of free trade and the free mobility of capital (Bargh, 2007). The reforms were described by some as an 'assault on the poor' because across-the-board benefit cuts, changes to employment legislation and the introduction of market rent in state housing, compounded by high structural unemployment (Asp, 2001). As this silent revolution continues unabated, the gap between rich and poor had grown exponentially. The most recent household survey confirms inequities within New Zealand remain embedded (Statistics New Zealand, 2014).

Social and political activism has ensured these issues remain before the public, and at times, the work of researchers who document such inequality has been of significant value. Prominent among these is the work of St John (2008) and other scholars, whose work lends significant support 
to the influence wielded by the Child Poverty Action Group 9 . This group has been successful in actively keeping child poverty on the political agenda. Rashbrooke (2014, p. iii) reviews the history of neo-liberal influence and asserts "income disparities pose serious economic, political and social risks, and raise acute ethical challenges". The positioning of New Zealand as a land of fairness, justice and equal opportunity to thrive still has a long way to go if these principles are to manifest in practice. The extent to which these ideals have been reached at all have, in large measure, come about through the pressure of activists.

\section{What is activism?}

Activism is the rent I pay for living on this planet $^{10}$

Activism occurs across the full range of the political spectrum, from the radical left to the conservative right and often takes place within the context of a social movement. It can be a means to express public dissatisfaction and to take action against those perceived to perpetrate social injustice. It can also be a means by which corporate-aligned activists seek to manufacture a mass populations' consent to exploit vulnerable markets, support war, instigate regressive economic reformation and initiate revolutio by stealth. Thus activism is a smorgasbord of activities designed to incite, impede or provoke social change. Actions can include demonstrations, marches, boycotts, blogging, public meetings, collecting petitions, and mutiny within institutions, developing intentional communities and/or occupations or skilful infiltration of public opinion by significant manipulation of popular culture (Laverack, 2013). Some of these initiatives will be within the law, others outside it. Whereas left-activism focuses on advancing social justice agendas, right-activism tends to serve conservative values that embed the privileges of an established elite (Hale, 2008b). Labour relations scholar Neilson (2013) maintains the challenge facing the left is global in scale and activists need to be ready to both dismantle and replace exploitative systems.

\section{Left wing activism}

Left-activism has historically been concerned with the long-term goals of justice, equity, sustainability and political and economic autonomy (Shields \& Somerville, 1994). Short-term attention often gets diverted into reacting to government policy, corporate activities and council endeavours that compromise these efforts. Ideally, left-activism should attempt to pursue longterm and short-term goals simultaneously. Such activism can manifest as highly visible and attention seeking street-based actions and/or take the form of more discrete radical community development approaches working with communities to create sustainable social change (Munford \& Walsh-Tapiata, 2006; Westoby \& Shevellar, 2012). This work is informed by a range of critical frameworks and paradigms including the writings of Karl Marx (2009/1887), Franz Fanon (1961/2004), David Korten (2001), Paulo Freire (1970/2000), Audre Lorde (1984), Susan George (2004) and Edward Herman and Noam Chomsky (2008)

\section{Activism in New Zealand}

I have laid down the law that there shall be no fighting and in the event of the two great tribes Māori and Europeans joining together to create a war it would be in vain, no

9 Their website http://www.cpag.org.nz/

10 Walker quoted in Ensar and Parmar (2013). 
fighting would ensure for my word has gone forth. ${ }^{11}$

Māori have engaged in what can broadly be defined as intergenerational activism in the pursuit of justice since 1840. They persistently resisted the imposition of British rule and colonisation (Harris, 2004). Māori have petitioned Parliament, the British Monarchy and the United Nations. They have occupied lands, organised short and long hikoi (marches), chopped down flagpoles and trees of national significance, pulled out survey pegs, and ploughed land to alert this nation to its unjust disposition. They have gone to war. They have taken to the streets and the courts to protect Māori interests. The campaigns of nonviolent/passive resistance led by Te Whiti o Rongomai and Tohu Kākahi at Parihaka, in Taranaki, in the face of the full military force of the settler government inspired Mahatma Gandhi and others in their later independence struggles (Scott, 1981). The work of Māori language activists in establishing Te Kōhanga Reo (Māori language nests) has inspired revitalisation programmes across the Pacific (LuafutuSimpson, 2006).

Alongside this indigenous activism, New Zealand has experienced waves of mobilisation and political activity centred around the trade union, anti-apartheid, peace/anti-war, environmental, unemployed, women's, disability and gay, lesbian and bisexual and trans rights movements (Alice \& Star, 2004; Coney, 1993; Downes, 2010; Locke, 2012; Locke, 1992; Richards, 1999; Taylor, 2008; Tennant, 1996). Pivotal landmarks in left activism in New Zealand include the bitter waterfront dispute of the 1950s which involved 22,000 workers engaging in industrial action for 151 days in pursuit of improved working conditions (Scott, 1954). In 1975 approximately 5000 Māori and other New Zealanders undertook a hikoi the length of the North Island to draw attention to Māori land issues. Their actions led to the formation of the Waitangi Tribunal (Harris, 2004). Intense conflict and mass demonstrations occurred in the early 1980s when antiapartheid protesters challenged the government's decision to allow the South African rugby team to tour New Zealand (Limb, 2008). In 1985, New Zealand was officially declared a nuclear-free zone in response to the concerted efforts of peace activists (Locke, 1992). Due to geographic isolation and the size of the politically active left within New Zealand, many activists often know one another, or of one another, and sometimes work in solidarity to address threats to social justice. Māori and Pākehā at times have worked together - and at times have stood apart. With the notable exception of the genocide unleashed against Māori during their resistance to colonisation (see Waitangi Tribunal, 1996), and the more contemporary raids on the Tühoe people (Gerzon, 2015), activism within a New Zealand context is comparatively safe compared to the violence perpetrated against activists in, for example, South Korea, the Philippines, Egypt, the United Kingdom and the United States (Dearey, 2010).

The last two decades has seen a steady growth in environmental activism in New Zealand. This has often been marked by an increasing convergence between some indigenous and Tauiwi opposition $^{12}$ to commonly perceived threats such as the introduction of genetically-engineered organisms, the extension of offshore deep-sea drilling and fracking projects (Peace Movement Aotearoa, 2014). In late 2011 occupy camps ${ }^{13}$ were established in a number of New Zealand cities, an experiment in the adaptation of an imported activist tactic whose local impact has yet to be

11 Te Whiti o Rongomai was the prophetic spiritual leader of the Parihaka movement with Tohu Kākahi in the late nineteenth century.

12 Tauiwi is an inclusive contemporary term for non-Māori New Zealanders; which implicitly includes a range of ethnic backgrounds.

13 The occupy movement is an international protest movement seeking a redistribution of resources to reduce inequalities often targeting large corporations and the global financial system (Van Gelder \& Staff of Yes! Magazine, 2011). 
adequately analysed. Currently, there has been a burst of renewed student activism, particularly through the "We Are the University" groups on a number of campuses and the re-emergence of an overtly political unemployed and beneficiary activism in the face of the exacerbation of income disparities.

\section{What is Activist scholarship?}

There's really no such things as the 'voiceless'.

There are only the deliberately silenced, or the preferably unheard ${ }^{14}$

Just as activism takes many forms, so does activist scholarship. To deepen this complexity, the broad discipline of activist scholarship is practised under a range of different names ${ }^{15}$ which denote subtle methodological, analytical and political distinctions. The authors maintain that the primary focus of research that could be categorised as left activist scholarship, is research intentionally designed to advance social justice agendas and challenge existing hegemonic power relations (Bradford, 2014). Activist scholarship embraces critical traditions and rejects what Hale (2008a, p. 3) calls the "privilege-laden option to remain outside the fray" and operates at the crossroads of research and political action. Feminists and other critical theorists such as Harding and Norberg (2005) have long held that the construction of knowledge is a political process. Activist scholars use the political process of knowledge-making to gather evidence to generate credible and powerful stories to inform and enrich activism.

Activist scholars have diverse focuses, ideas and inspirations but have shared political sensibilities that reflect a commitment to what Hale (2008b, p. 7) describes as "social justice that is attentive to inequalities of race, gender, class and sexuality and aligned with struggles to confront and eliminate them". Neilson $(2011,2013)$ argues activist scholars also present paradigm-shifting discourses to co-create peaceful, sustainable and resilient intentional communities. Bisaillon (2012, p. 610) asserts that activist scholars are often active members of activist organisations and are committed to producing knowledge from the perspective of people occupying places of marginality. Activist scholars are therefore both thinkers and doers and commonly engage in applied research that has a political purpose.

Distinct from its participatory action research origins, activist scholarship is concerned with the distinction between what kaupapa Māori ${ }^{16}$ theorist Cram calls procedural and outcome empowerment (Cram, 1997). Procedural empowerment, she maintains, is transient and occurs when research participants feel heard and believe their participation in the research was worthwhile. Outcome empowerment, which is more durable, emerges when successful social and political action occurs resulting from that research. Feminist scholar Neal (1995) maintains the challenge for activist scholars is to move past rhetoric and good intentions into sustainable resilient social change outcomes.

Along with its explicitly articulated political focus, Hale (2008b) argues activist scholars deliberately take great care to meet the normative research standards of rigor. Attention is paid to research design to ensure the reliability and validity of data and that sampling strategies generate sufficient information to produce credible findings. Ethical approval is sought from relevant academic bodies and additional layers of accountability mechanisms and/or governance

14 Roy, 4 November 2004

15 These related methodological traditions include: branches of critical, liberation and feminist theory, participatory action research, and some kaupapa Māori traditions.

16 Kaupapa Māori theory is grounded in a Māori epistemological and ontological standpoint. 
arrangements are also often negotiated with activist and partnered communities. Long-term and ongoing connections with communities' demand careful and thoughtful engagement and active vigilance of power dynamics. However, aligned with the critical tradition, activist scholars commonly reject positivist claims of objectivity in research (Harding, 1993). Sjoberg (1971) argues activist scholars instead engage in thorough examination of the impact of ethical and political decisions on research projects. Researchers with this orientation often feel compelled to work harder than most to validate a sense of trustworthiness in this emerging genre.

An iconic New Zealand example of activist scholarship was the Race Gender Class journal of the 1980s and 1990s. The brainchild of the late Rob Steven, the journal was hosted by Canterbury University, with an editorial team gathered from across the radical-left. The journal was founded on a commitment to exposing and theorising oppression and to building a unified radicalleft. Alongside academic papers the journal contained detailed interviews with busy activists punctuated with political cartoons. The journal also intentionally utilised Te Reo Māori (Māori language) summaries of most articles as a way to support language revitalisation. The content, editorial and production process were all designed to be transformative, to build dialogue and strengthen capacity in a new generation of activists.

\section{Exploring the role of the activist scholar}

...a privileged minority western democracy provides the leisure, the facilities, and the training to seek the truth behind the veil of misrepresentation, ideology and class interest through which the events of current history are presented to us. To neglect that responsibility is, at the very best acquiesce to oppression. ${ }^{17}$

Access to education is a human right but, as Chomsky (1969) argues, access to (tertiary) education is still considered a privilege. The life of an academic is a rare life of being paid to think, write, supervise and facilitate learning. The relationships between academics and activist communities within the New Zealand context are a largely under-researched phenomenon. Anecdotal evidence, from conversations the authors have had with activists to inform this article, revealed various standpoints. Some activists perceive academics as having 'sold out' by their participation in the neo-liberal university system. Others share painful stories of collaboration projects gone wrong, where academics were deemed to be the only beneficiaries of the research process. Still others question how or when writing an academic paper and theorising around an issue has ever made a difference - academics, they argue, have made themselves inaccessible and irrelevant to the pursuit of justice.

Rather than producing research outputs, some activists want 'all hands on deck' to support urgent struggles to alleviate oppression. Others saw the university and activist scholars as an opportunity to have activists in paid positions with useful access to resources and information. Thus placed, scholars can use these roles to theorise, analyse, generate evidence, and translate complex information into usable formats. Academics can also draw on their expertise as appropriate to support new activists in a mutually beneficial relationship. They can also broker networks and information, bringing people together to advance social justice agendas. An absence of social justice orientated scholars would also not bode well for the teaching of all subject matter at the tertiary level.

A range of opportunities are available for activist scholars to contribute to social movements

17 Chomsky, 1969, p. 324 
and political activism from their position in academia - mostly paid for by the public purse. As both activists and academics activists scholars can provide a bridge between both communities. We can share useful analysis and case studies such as the work of Jane Kelsey (2013), Walker (1990) and Salmond (1992) to contextualise and amplify campaigns for justice. We can share lived experiences of oppression and the unique challenges of campaigning back into the academy, since the Academy itself is not without its oppressions (Stockdill \& Danico, 2012). As seasoned activists, we mourn the loss of social history with the passing of elders that held the institutional knowledge and oral history of movements and the marginalization of critical debate, independent documentaries and satire in the mass media. Many of these were esteemed researchers and teachers. As scholars we could take more responsibility to strengthen archival records and contemporary archiving practices. We can add our voices in solidarity to amplify the voices from those on the margins. We can use our time to challenge flawed analysis in the mass media and articulating for a wider readership the complexity of issues.

Often within our professional lives we are required to use strategic planning and evaluation skills to shape and progress projects, institutional mandates and personal careers. These are skills that can be made useful for a bridge between scholars and activists. Intentionally focussed on engagement with the transformation of injustice, these commitments can become activist research. What do we need to know to ensure our activism is effective from both an outcome and a process point of view? What lessons have we learnt that can be appropriately shared within public domains? From our experiences in the field we have identified issues around sustainability and burnout, maintaining momentum within campaigns, and the pressure to be reactive rather than proactive in our activism as examples of potentially useful sites for research designed to strengthen activism.

We are clear that the role of activist scholars is not to be an expert in all the dimensions in which activists operate. Rather, it is to engage in what Hale (2008a) calls horizontal dialogue with activist communities, to define research questions and to inform data analysis so it can reveal previously unseen or inadequately understood patterns. Activist scholars can critically reflect

Table 1: Proposed Principles of Activist Scholarship

Activist scholarship is committed to:

1. inclusive social justice (both people and planet)

2. working with activists to challenge existing power relations

3. scholarship and action informed by intergenerational knowledge

4. political struggle and critique and/or building radical communities

5. gathering credible evidence and powerful stories to inform activism

6. rejecting objectivity and embrace (ethical and political) complexity

7. robust research process and concrete social change outcomes 
on activist praxis informed by both scholarship and experiences of activism. The effectiveness of these collaborations reflects the quality of relationships between individual activist scholars and activist communities in a given time and place. Rather than the usual top-down academicinformant dynamic, activist scholarship embraces a flattened structure of academic working with knowledgeable, experienced, empowered activist colleagues.

\section{Proposed Principles of Activist Scholarship}

We are interested to articulate some principles that give voice to fundamental assumptions or foundations of activist scholarship. After reviewing the international literature and entering into debate with local activist scholars we propose seven principles of activist scholarship (see Table 1). These principles are overlapping and evolving. We maintain it is not necessary for all of these principles to be present for a piece of work to be considered activist scholarship, but we argue many of them will be present if scholarship is to be considered consciously activist.

The first principle in Table 1 speaks to the activist scholar's relentless pursuit of social justice - of fairness and equity. Informed by indigenous scholarship this principle recognises the interconnections of the holistic health and wellbeing of Papatūānuku (Earth Mother) and her human inhabitants. It touches on how securing justice for people at the expense of the planet is short-sighted and the ultimate end-game is the quest for social justice globally.

The second principle affirms the critical tradition of scholarship that prioritises exposing and challenging existing unequal power differentials. This challenge, rather than coming exclusively from the academy, is informed by flax-roots activists. This principle speaks to the centrality of collaboration and partnership between the activist scholar and the wider activist community to ensure work is politically astute.

The third principle speaks of the importance of building on existing scholarship and entering into dialogue with activist elders. Often activist learnings may not be written down in formal scholarship, so ongoing dialogue with elders is a rewarding way to capture insights gleaned from active politically engaged lives. It also ensures activist scholars stay in contact with activist communities and maintain their accountability to the relevant social movement to which they are committed.

The fourth principle celebrates that activist scholarship is both critiquing and challenging those that are abusing power and, on the other hand, is about building new radical communities and ways of being. Both ends of this spectrum fit within the domain of the activist scholar.

The fifth principle is recognising that social change is about moving people, engaging people and shifting and challenging peoples' perception. Activist scholars, like all scholars, are interested in generating robust credible evidence that can stand up to hostile political scrutiny to inform debate. This evidence may be quantitative or qualitative data, but the act of activist scholarship is in weaving it into compelling stories to support the pursuit of social justice.

The sixth principle celebrates activist scholars' rejections of positivistic notions of objectivity. This principle encourages activist scholars to avoid easy ideological positions and instead embrace political and ethical complexity. This pursuit of complexity serves to diffuse accusations of bias from those less familiar and comfortable with political research standpoints pioneered by feminist scholarship.

The final principle speaks of an ethical commitment to robust research that will stand up to political and scholarly scrutiny. It emphasises the importance of activist scholarship contributing to concrete political outcomes defined with activist communities.

So what does activist scholarship look like on the ground? In the New Zealand context at 
the heart of our work is a commitment to Te Tiriti o Waitangi and supporting the restoration of tino rangatiratanga (Māori sovereignty). Our illustrative example focuses on the development of Ngāpuhi Speaks, an independent Waitangi Tribunal report. The project highlights anti-racism praxis and illustrates several of the proposed core principles set out in Table 1.

\section{Co-intentionality: Restoring Sovereignty}

Within New Zealand the Pākehā/Tauiwi/Tangata Tiritit ${ }^{18}$ movement has a tradition of activist scholarship committed to both documenting the stories of our work and to strengthening anti-racism praxis (see for example Huygens, 2007; Margaret, 2002a, 2002b, 2013; Nairn, 2002). Activists within this movement such as Kirton (1997) and Humphries (1992) are commonly known as Tiriti workers and subscribe to a collective ethic of working towards a society based on Te Tiriti o Waitangi which is consistent with the aspirations of local hapū (Network Waitangi Ōtautahi, 2002). The descendants of the colonisers work in what Freire (1970/2000) calls cointentional relationships. This work has been explicitly and implicitly applied by Tiriti workers to inform their support of the restoration of Māori tino rangatiratanga (sovereignty). Governance and collaborative arrangements are often negotiated with Māori to ensure clear accountability arrangements around such activism. Ngāpuhi Speaks, our chosen example for this paper, illustrates the activist scholarship generated in treaty related anti-racism work.

\section{Ngāpuhi Speaks}

A recent example of what could be described as activist scholarship within a movement, has been the alternative Waitangi Tribunal report Ngāpuhi Speaks (Healy et al., 2012). This report was commissioned on behalf of kaumātua and kuia (elders) of Ngāpuhi Nui Tonu. They were concerned about the integrity of the official Waitangi Tribunal process. The project was made possible because of long-standing relationships of trust, between some mana whenua (local Māori) and some Pākehā anti-racism activists from Network Waitangi Whangarei and by resourceful fundraising efforts. The report was written by a Māori decolonisation expert and two Pākehā activist scholars who were supported by a local kaumātua who acted as kaitiaki (guardian) for the project. The authors met regularly with the elders who commissioned the report, before, after and during the hearings, to ensure the political and cultural nuances of Ngāpuhi viewpoints were accurately documented.

The report summarises five weeks of Ngāpuhi evidence around Te Tiriti o Waitangi and the Declaration of Independence based on oral histories from Ngāpuhi elders descended from those who signed Te Tiriti and evidence generated from both English-language and Te Reo Māori primary sources. It meticulously summarises the evidence presented by Ngāpuhi, to definitively and powerfully fracture the widely held view that Māori ceded sovereignty to the British in 1840 and was affirmed in the subsequent official Waitangi Tribunal (2014) report. The report concludes with practical recommendations for the Crown and to Ngāpuhi Nui Tonu ${ }^{19}$, the people of New Zealand, the media and Elizabeth II, Queen of England and New Zealand. The report was launched in late 2012 and at the time of writing has already had two print runs and has been released as an e-book. The report is used to generate deeper understandings and political action to affect change. It has been widely circulated and discussed within Ngāpuhi whānau (families)

18 Tangata Tiriti refers to people who recognise they have a right to live in New Zealand under Te Tiriti o Waitangi in contrast to Tangata Whenua - indigenous people of the land.

19 Ngāpuhi Nui Tonu refers to the network of hapū that connected to Ngāpuhi. 
and hapū (sub-tribes) and the ripples of its impact are still unfolding within Māori communities. Anecdotal feedback from Tauiwi communities suggests the report has been paradigm shifting in; i) deepening understandings of the significance of He Wakaputanga; ii) raising awareness of the issues around the imposition of Crown unitary sovereignty, and; iii) as a seminal critique of populist misrepresentations of New Zealand history. The report has been incorporated into curriculum and reading lists in tertiary institutions and has been cited in a number of submissions to the current constitutional review (Brookes, 2013; Healy, 2013; MacDonald, 2013).

The Ngāpuhi Speaks story (thus far) is an example of activist scholarship that is consistent with the principles we are offering as a guide for activist researchers. It shows a commitment to social justice, models activists working to challenge existing power relations and critiquing dominant hegemonic discourses. Those involved in the project utilised intergenerational knowledge, gathered credible evidence and powerful stories to inform activism. Their research process was robust and embraced complexity of capturing the nuances of multiple indigenous voices for the concrete social change outcome of supporting Ngāpuhi in their quest to secure the return of their land and tino rangatiratanga.

Robust and well established scholarly work anchored the story. Critical race theory (CRT) is a race-equity methodological approach originated from the United States that deliberately focuses on exposing racism, how it is created and maintained. The approach has a commitment to social justice, an emphasis on political and historical context and deliberately amplifies the voices of people targeted by racism. CRT is multi-disciplinary and is intended to elucidate contemporary racial phenomenon (Ford \& Airhihenbuwa, 2010). Storytelling is often used within CRT to contrast what Gillborn (2006) describes as master narratives - voices of the powerful, with counter narratives - the voices of those marginalised. Bauman and Donskis (2013) invite a reflection on a treachery that derives from the chance, fortune and practice of the situational pragmatist - the person perhaps too easily deflected from a recognition that 'something is amiss' and who has various explanatory stories to avoid close scrutiny of self or situations. They may be guided by an instrumental ethic that allows one to build one's legend at other people's expense, "using them as situations, fragments, and individual components of one's own project" (Bauman and Donskis 2013, p.217). The juxtaposition of the stories that cohere as a grand narrative with the stories of those whose experiences bring this dominant view of the world into question may evoke dissonance and discomfort. Unflinching attention to this unsettling discomfort can lead to an enhanced critical consciousness. This form of attentiveness becomes an ethical gaze that could provoke a response - an action that may contribute to the achievement of justice. As activist researchers, the exposure of and attention to inconsistencies between stories of ourselves as a 'just people' and the stories that bring such assessment into question invite an ethical gaze as invited by Bauman and Donskis (2013) and an activist response as we are proposing in this paper.

\section{Finding ways forward}

Activist scholarship is a complex and emerging field of scholarship. It can involve advocacy for immediate and necessary equitable service provision across all structural inequities. It may involve long slow collaborative processes, negotiated over time that expose colonial deceit and actively models reconfigured power relations. Activist scholarship offers rich opportunities to deepen and enrich relationships, to consolidate analysis and to bolster social justice action.

So, strategically what needs to be done to strengthen activist scholarship in New Zealand and beyond? We invite more collective activist engagement among scholars. As a Cherokee activist argues "the system can handle thousands of 'oppositional' individuals who do work on their own; 
it is through collective action that change is most likely to occur" (Smith, 2009, p. 37). Such an intentional network could allow us to learn more about the complexities of the political agendas of the radical left, as argued for by Bradford (2014) and create a more coherent understandings of what we are resisting and trying to build. It could also allow us the opportunity to share learnings within our niche areas of activism to strengthen resistance. International cyber communities are a wonderful resource, but we also need face to face time with local activist scholars to forge relationships and solidify collaboration.

As activist scholars we support attempts to build deeper engagement and relationship between activist communities and the academy. Anticipating scrutiny, we need to be meticulous in our practice. We need to ensure we maintain horizontal dialogue and clear accountability mechanisms with our activist colleagues, so as to build trust and ensure our work is relevant and useful. The challenge for activist scholars is not to endlessly describe social problems, as is widespread within the academy, but to generate compelling evidence, cogent commentary and sustainable solutions to affect resilient social change. Consequently, research funders need to be enticed into re-orientating funding to accommodate examination of both the deep causes and deep solutions of inequities.

As activist scholars, we need to continue to fracture the myth of objectivity in research and continue to argue for the validity of first person voices and lived experiences as significant and valuable evidence (Harding, 2005). We need to analyse seemingly neutral data to expose the previously unseen patterns of profit, power and privilege as substantive evidence of systemic structural violence. As critical theorists we need to continue to consciously and transparently reflect on the socio-political conditions that inform research questions and processes, and on the scope of research projects. We need to also remain focussed on our own practice, to ensure no harm comes to our allies, and take time to reflect and write up our learnings so others can benefit from our successes, blunders and missed opportunities.

Formalised activist scholarship is controversial in the context of the New Zealand academy - with little yet published explicitly on the subject, but its roots in radical and critical traditions are long standing. With our mind on Aotearoa, it is crucial for activist research to interrogate the intersection of tino rangatiratanga, Te Tiriti o Waitangi, and the New Zealand Crown, if indigenous needs, rights and aspirations are to be attained. Rich in elders within the radical left in New Zealand, we need to consider how we can share this wealth of knowledge with the international community while embracing the fresh insights of young activists. Entrenched in niche-based activism, we need to find new ways to transcend the traditional demarcations of race, gender, class, sexuality, peace, disability and caring for the planet, so that our approach is more strategic. It might be uncomfortable to step out of the familiar but with the current systemic and global challenges to peace and justice it may well be time for a new paradigm. 


\section{References}

Alice, L., \& Star, L. (2004). Queer in Aotearoa New Zealand. Palmerston North, New Zealand: Dunmore Publishing.

Asp, J. (2001). The experiment in New Zealand: The consequences and experiences of the reforms in New Zealand. Copenhagen, Denmark: General Workers Union.

Bargh, M. (2007). Resistance: An indigenous response to neo-liberalism. Wellington, New Zealand: Huia.

Bauman, Z., \& Donskis, L. (2013). Moral blindness: The loss of sensitivity in liquid modernity. Cambridge, England: Polity Press.

Bisaillon, L. (2012). An analytic glossary to social inquiry using institutional and political activist ethnography. International Journal of Qualitative Methods, 11(5), 607-627.

Bishop, R., Berryman, M., Cavanagh, T., \& Teddy, L. (2009). Te kotahitanga: Addressing educational disparities facing Māori students in New Zealand. Teaching and Teacher Education, 25(5), 734-742. doi: 10.106/j. tate.2009.01.009

Bradford, S. (2014). A major left wing think tank in Aotearoa - an impossible dream or a call to action? (Unpublished Doctoral thesis), Auckland University of Technology, Auckland, New Zealand.

Brookes, J. (2013). Submission to the government appointed constitutional advisory panel. Auckland, New Zealand: Auckland Social Justice Council of the Anglican Church in Aotearoa, New Zealand and Polynesia.

Chomsky, N. (1969). American power and the new mandarins. New York, NY: Pantheon Books.

Coney, S. (1993). Standing in sunshine: A new history of New Zealand women since they won the vote. Auckland, New Zealand: Viking Press.

Cram, F. (1997). Developing partnerships in research: Pākehā researchers and Māori research. Sites: A Journal of Radical
Perspectives on Culture, 35, 44-63.

Crenshaw, K. (1989). Demarginalizing the intersection of race and sex: A Black feminist critique of antidiscrimination doctrine, feminist theory and antiracist politics. University of Chicago Legal Forum, 139-167.

Dearey, M. (2010). Radicalization: The life writings of political prisoners. New York, NY: Routledge.

Downes, D. (2010). The New Zealand environmental movement and the politics of inclusion. Australian Journal of Political Science, 35(3), 471-491. doi: 10.1080/713649347

Fanon, F. (2004). The wretched of the earth (R. Philcox, Trans.) (First ed. 1961). New York, NY: Penguin Books.

Freire, P. (2000). Pedagogy of the oppressed (M. Ramos, Trans.) (First ed. 1970). New York, NY: Continuum.

Ford, C., \& Airhihenbuwa, C. (2010). Critical race theory, race equity, and public health: Towards antiracism praxis. American Journal of Public Health, 100(S1), S30-S35. doi: 10.2105/AJPH.2009.171058

Gasson, N. (1998). Liberalism, communitarianism, fairness and social policy. (Unpublished doctoral thesis), Otago University, Dunedin, New Zealand.

George, S. (2004). Another world is possible if... London, England: Verso.

Gerzon, R. (2015). A sincere form of love - stories that need to be told. In H. Came \& A. Zander (Eds.), State of the Pākehā nation: Collected Waitangi day speeches and essay 206-2015 (pp. 88-94). Whangarei, New Zealand: Network Waitangi Whangarei.

Gillborn, D. (2006). Critical race theory and education: Racism and anti-racism in educational theory and praxis. Discourses: Studies in the Cultural Politics of Education, 27(1), 11-32. doi: 


\section{$10.1080 / 01596300500510229$}

Grimshaw, P. (1994). Women's suffrage in New Zealand revisited: Writing from the margins. In C. Daley \& M. Nolan (Eds.), Suffrage and beyond: International feminist perspectives. New York NY: New York University Press.

Hackett Fischer, D. (2012). Fairness and freedom: A history of two open societies: New Zealand and United States. New York, NY: Oxford University Press.

Hale, C. (2008a). Engaging contradictions: Theory, politics and methods of activist scholarship. Los Angeles, CA: University of California Press.

Hale, C. (2008b). Introduction. In C. Hale (Ed.), Engaging contradictions: Theory, politics and methods of activist scholarship (pp. 1-30). Los Angeles, CA: University of California Press.

Harding, S. (2005). Negotiating with the positivist legacy: New social justice movements and a standpoint politics of method. In G. Steinmertz (Ed.), The Politics of Method in the Human Sciences (pp. 346-366). Durham, England: Duke University Press.

Harding, S., \& Norberg, K. (2005). New feminist approaches to social science methodologies: An introduction. Signs: Journal of Women in Culture and Society, 30(4), 2009-2015. doi: $10.1086 / 428420$

Harris, A. (2004). Hikoi: Forty years of Maori protest. Wellington, New Zealand: Huia.

Healy, S. (2013). Constitutional conversation (submission to constitutional review). Auckland, New Zealand.

Healy, S., Huygens, I., \& Murphy, T. (2012). Ngāpuhi speaks. Whangarei, New Zealand: Network Waitangi Whangarei, Te Kawariki.

Herman, E., \& Chomsky, N. (2008). Manufacturing consent: The Political Economy of the Mass Media. London, England: The Bodey Head.

Human Rights Commission. (2011). A fair go for all? Structural discrimination and systemic barriers to ethnic equality. Wellington, New Zealand: Author.
Humphries, M. (1992). Working with our differences: New Zealand experiences. Journal of Management Education, 16(4 Suppl), 28-42.

Huygens, I. (2007). Process of Pākehā change in response to the Treaty of Waitangi. (Doctoral dissertation), Waikato University, Hamilton, New Zealand. Retrieved 10/8/14 http://researchcommons.waikato.ac.nz/ bitstream/10289/2589/1/thesis.pdf.txt

Johnson, A. (2015). A mountain we can all climb: A state of the nation report from the Salvation Army. Auckland, New Zealand: Salvation Army.

Kelsey, J. (1995). The New Zealand experiment: A world model for structural adjustment? Auckland, New Zealand: Auckland University Press with Bridget Williams Books.

Kelsey, J. (2013). Hidden agendas: What we need to know about the TPPA, Auckland, New Zealand: Bridget Williams Books.

Kirton, J. (1997). Pākehā / Tauini: Seeing the 'unseen': Critical analysis of the links between discourse, identity, blindness and encultured racism. Kirikiriroa, New Zealand: Waikato Anti-racism Coalition.

Korten, D. (2001). When corporations rule the world. San Francisco, CA: Berrett-Koehler Publishers.

Kuchler, B. L. (2003). That's Life: "Wild" Wit \& Wisdom, Minocqua, WI: Willow Creek Press.

Laverack, G. (2013). Health activism: foundations and strategies. London, England: Sage.

Limb, P. (2008). The anti-apartheid movements in Australia and Aotearoa/New Zealand. In South African Democracy Education Trust \& G. Houston (Eds.), The road to democracy in South Africa (Vol. 3). Pretoria, South Africa: University of South Africa Press.

Locke, C. (2012). Workers in the margins: Union radicals in post-war New Zealand. Wellington, New Zealand: Bridget Williams Books.

Locke, E. (1992). Peace people: A bistory of peace activities in New Zealand. Christchurch, New Zealand: Hazard Press.

Lorde, A. (1984). The master's tools will never dismantle the masters' house in Sister outsider: Essays and speeches (pp. 110-113). New York, NY: The Crossing Feminist Press.

Luafutu-Simpson, P. (2006). Choices offered, choices chosen in Pasifika early childhood education. (Unpublished masters thesis), Canterbury University, Christchurch, New Zealand. Retrieved 10/8/14 from http://ir.canterbury. 
ac.nz/bitstream/10092/987/1/thesis_fulltext. pdf

MacDonald, J. (2013). Submission to the constitutional advisory panel from Tamaki Treaty Workers. Auckland, New Zealand: Tamaki Treaty Workers.

Margaret, J. (2002a). Pākehā treaty work: Unpublished material. Manukau, New Zealand: Manukau Institute of Technology, Treaty Resource Centre.

Margaret, J. (2002b). Pākehā treaty work: An annotated bibliography. Auckland, New Zealand: Manukau Institute of Technology, Treaty Resource Centre.

Margaret, J. (2013). Working as allies: Supporters of indigenous justice reflect. Auckland, New Zealand: Auckland Workers Educational Association.

Marriott, L., \& Sim, D. (2014). Indicators of inequality for Māori and Pacific people [Working paper 09/2014]. Wellington, New Zealand: Victoria University.

Marx, K. (2009). Das keapital: Critique of political economy (S. Moore and E. Aveling Trans.) (First ed. 1887) (Vol. 1). Moscow, USSR: Progress Publishers.

Ministry of Health and University of Otago. (2006). Decades of disparity three: Ethnic and socioeconomic inequalities in mortality, New Zealand 1981-1999 (Public Health Intelligence Occasional Bulletin No.31) Retrieved 10/8/14 from http:/ /www.moh.gvt. nz/ moh.nsf/pagesmh/4702/\$File/decadesof-disparity-III.pdf

Moewaka Barnes, H., Borell, B., \& McCreanor, T. (2014). Theorising the structural dynamic of ethnic privilege in Aotearoa: Unpacking "this breeze at my back". International Journal of Critical Indigenous Scholarship, 7(1), 1-14.

Munford, R., \& Walsh-Tapiata, W. (2006). Community development: working in the bicultural context of Aotearoa. Community Development Journal, 41(4), 426-442. doi: $10.1093 / \mathrm{cdj} / \mathrm{bsl1025}$

Nairn, M. (2002). Programme on racism collected newsletters 1985-2002. Auckland, New Zealand: Treaty Conference Publications Group.

Neilson, D. (2011). Joining the dots: Discourse and strategy in the making of a counter hegemonic project beyond neoliberal global capitalism. Paper presented at the Journalism, Media and Democracy Conference, Auckland, New Zealand.

Neilson, D. (2013). Beyond neoliberalism: Discourse, practice and strategy. Hoblin, 4.

Network Waitangi Ōtautahi. (2002). Protocols and ethics for Network Waitangi tiriti workers. In J. Margaret (Ed.), Pākehā treaty work: Unpublished material (pp. 214-215). Auckland, New Zealand: Manukau Institute of Technology, Treaty Resource Centre.

Orange, C. (2011). The Treaty of Waitangi (2nd ed.). Wellington, New Zealand: Bridget Williams Books.

Ensler, E \& Parmar, P. (2013). Alice Walker: Beanty in Truth [Motion picture] USA and UK.

Paxton, P., \& Hughes, M. (2007). Women, power and politics: A global perspective. New York, NY: Sage Publications.

Peace Movement Aotearoa. (2014). NGO information for the Human Rights Committee, 110 session: List of Issues Prior to Reporting, New Zealand Author. Wellington, New Zealand. Retrieved 10/8/14 from http://tbinternet.ohchr.org/Treaties/ CCPR/Shared\%20Documents/NZL/INT_ CCPR_NGO_NZL_17002_E.pdf

Rashbrooke, M. (2014). The inequality debate: An introduction. Wellington, New Zealand: BWB Texts.

Rei, T. (1993). Māori woman and the vote. Wellington, New Zealand: Huia Publishers.

Richards, T. (1999). Dancing on our bones: New Zealand, South Africa, rugby and racism. Wellington, New Zealand: Bridget Williams Books.

Robson, B. (2007). Economic determinants of Maori health and disparities. In M. Bargh (Ed.), Resistance: An indigenous response to neoliberalism (pp. 45-61). Wellington, New Zealand: Huia.

Roy, A. (2004). Peace and the new corporate liberation theology. Paper presented at the 2004 Sydney peace prize lecture, Sydney, Australia. http:// sydney.edu. au/news/84.html? newsstoryid $=279$

Salmond, A. (1992). Two worlds: First meetings between Maori and Europeans 1642-1772. Honolulu, HA: University of Hawaii Press.

Scott, D. (1954). 151 days: New Zealand Waterside Workers Union. Wellington, New Zealand: Southern Cross Books.

Scott, D. (1981). Ask the mountain. Auckland, New Zealand: Reed.

Sheridan, N., Kenealy, T., Connolly, M., Mahony, F., Barber, A., Boyd, M. A., . . Moffitt, A. (2011). Health equity in the New Zealand health system: A national survey. International Journal for Equity in Health, 10(1).

Shields, K., \& Somerville, P. (1994). In the tiger's mouth: An empowerment guide for social action. 
Philadelphia, PA: New Society

Sjoberg, G. (1971). Ethics, politics and social research. New York, NY: Schenkman.

Smith, A. (2009). Native studies and critical pedagogy: Beyond the academic-industrial complex. In J. Sudbury \& M. Okazawa-Rey (Eds.), Activist scholarship: Antiracism, feminism and social change (pp. 37-55). London, England: Paradigm Press.

St John, S., \& Wynd, D. (2008). Left bebind: How social and income inequalities damage New Zealand children. Auckland, New Zealand: Child Poverty Action Group.

Statistics New Zealand. (2014). Household economic survey Wellington, New Zealand: Author.

Stockdill, B., \& Danico, M. (Eds.). (2012). Transforming the ivory tower: Challenging racism, sexism and homophobia in the academy. Honolulu, HI: Hawai'i Press.

Taylor, D. (2008). What's left? An exploration of social movements, the Left and activism in New Zealand Today. (Unpublished masters thesis), Victoria, Wellington, New Zealand. Retrieved 10/8/14 from http://researcharchive.vuw. ac.nz/bitstream/handle/10063/1259/thesis. pdf? sequence $=1$

Tennant, M. (1996). Disability in New Zealand: An historical survey. New Zealand Journal of Disability Studies, 2, 3-33.

United Nations. (1948). Universal declaration of buman rights Retrieved 10/8/14 from http://www. un.org/en/documents/udhr/

Van Gelder, S., \& Staff of Yes! Magazine. (2011). This changes everything: Occupy Wall Street and the 99\% movement. San Francisco, CA: BerrettKoehler Publishers.

Waitangi Tribunal. (1996). The Taranaki report: Kaupapa tuatabi [WAI 143] Retrieved 10/8/14 from http://www.waitangi-tribunal.govt.nz/ scripts/reports/reports/143/55B2A0E3DD7B-4E1B-A824-9F046DECD328.pdf

Waitangi Tribunal. (2014). Te paparahi o te raki [Wai 1040]. Wellington, New Zealand: Author.

Walker, R. (1990). Ka whawhai tonu mātou: Struggle without end. Auckland, New Zealand: Penguin Books.

Westoby, P., \& Shevellar, L. (2012). Learning and mobilising for community development: A radical tradition of community-based education and training. Surrey, England: Ashgate Publishing.

Wilson, M. (2014). Precarious work - New Zealand experience. New Zealand Journal of Employment
Relations, 39(2), 22-33.

World Economic Forum. (2014). The global gender gap report. Geneva, Switzerland: Author. 